\title{
Educational and labor inclusion of the elderly in the UAEM
}

\section{Inclusión educativa y laboral del adulto mayor en la UAEM}

\author{
MORENO-AGUIRRE, Alma Janeth ${ }^{1} \dagger$, GUAJARDO-RAMOS, Eliseo ${ }^{1 *}$, ORTIZ-RODRÍGUEZ, María \\ Araceli $^{2}$ and DELGADO-SÁNCHEZ, Ulises ${ }^{1}$
}

${ }^{1}$ Faculty of Human Communication, Universidad Autónoma del Estado de Morelos (UAEM)

${ }^{2}$ Faculty of Nutrition, UAEM

ID $1^{\text {st }}$ Autor: Alma Janeth, Moreno-Aguirre / ORC ID: 0000-0001-9076-5987, CVU CONACYT ID: 173543

ID $1^{\text {st }}$ Coautor: Eliseo, Guajardo-Ramos / ORC ID: 0000-0002-1477-0167, CVU CONACYT ID: 265589

ID $2^{\text {nd }}$ Coautor: María Araceli, Ortiz-Rodríguez / ORC ID: 0000-0003-0847-0261, Researcher ID Thomson: T-3707-2018, CVU CONACYT ID: 449164

ID $3^{\text {rd }}$ Coautor: Ulises, Delgado-Sánchez / ORC ID: 0000-0002-4318-0238, CVU CONACYT ID: 75156

DOI: $10.35429 /$ EJC.2020.6.11.25.31

Received July 18, 2020; Accepted November 30, 2020

\begin{abstract}
Objective. Analyze the process of educational and labor inclusion of the elderly in higher education of the UAEM. Methodology. An analysis of the process of educational and labor inclusion in the older adult population who are workers and students of the UAEM was carried out. The needs they present, the conditions in which they are found, and the supports provided were identified. This analysis was carried out from a cognitive, neurobiological perspective with or without the presence of disability or chronicdegenerative disease; as well as the search for socioaffective indicators or other psychosocial factors that may impact this inclusion process. Contribution. The results obtained will allow establishing strategies to improve the process of educational and labor inclusion in this population considered as vulnerable.
\end{abstract}

Elderly, Educational and Labor Inclusion, Higher Education

\begin{abstract}
Resumen
Objetivo. Analizar el proceso de inclusión educativa y laboral del adulto mayor en educación superior de la UAEM. Metodología. Se realizó un análisis del proceso de inclusión educativa y laboral en población adulta mayor que son trabajadores y estudiantes de la UAEM. Se identificaron las necesidades que presentan, las condiciones en las que se encuentran y los apoyos brindados. Este análisis se realizó bajo la perspectiva cognitiva, neurobiológica con o $\sin$ presencia de discapacidad o enfermedad crónicodegenerativa; así como la búsqueda de indicadores socioafectivos $\mathrm{u}$ otros factores psicosociales que puedan impactar en este proceso de inclusión. Contribución. Los resultados obtenidos permitirán establecer estrategias para mejorar el proceso de inclusión educativa y laboral en esta población considerada como vulnerable.
\end{abstract}

Adulto Mayor, Inclusión Educativa y Laboral, Educación Superior

Citation: MORENO-AGUIRRE, Alma Janeth, GUAJARDO-RAMOS, Eliseo, ORTIZ-RODRÍGUEZ, María Araceli and DELGADO-SÁNCHEZ, Ulises. Educational and labor inclusion of the elderly in the UAEM. ECORFAN Journal-Republic of Colombia. 2020. 6-11: 25-31

\footnotetext{
* Correspondence to Author (email: eliseo@uaem.mx)

$\dagger$ Researcher contributing as first author.
} 


\section{Introducción}

The human being always presents modifications in his state of health, which can be both favorable and unfavorable changes throughout life, if observed from the biopsychosocial model where there is presence of both biological, psychological and social factors that will influence his well-being. However, despite neurobiological, affective, social and cultural conditions, among others; there will be a need for the person to grow in different areas and periods of development, such as in childhood, adolescence, adulthood and without hesitation also in the older adult stage (Ceh, 2020; MorenoAguirre, Ortiz-Rodríguez, Cruz Abarca \& Capistrán-Pérez, 2019).

In Mexico, the person considered as Elderly in accordance with the H. Congress of the Union, is one who is sixty years old or over and who is domiciled or in transit in national territory, the same criteria used by the Official Mexican Standard NOM-167 -SSA1-1997 used by the Ministry of Health (Moreno-Aguirre et al., 2019; Saldaña-Ibarra \& Hernández-Guerson, 2017).

Although there has always been an interest in ensuring the health of the elderly population, actions in general are more aimed at neurobiological well-being, as reported by Benavidez-Caro (2017), about the implementation of policies focused on the management of older adults, and patients at risk of dementia and cognitive alterations, which allow the development of physical activity programs for the elderly, programs for the control of chronic-degenerative diseases, programs to avoid smoking, etc.

These programs support the human rights of the elderly, not only by seeking and preserving their physical health, which has increased life expectancy and at the same time new needs in order to have a quality of life in all spheres of the biopsychosocial model. In recent decades, the average age of the elderly has increased, by 2014 life expectancy of women reached 77.5 years and that of men 72.1 years, ages that will increase by 2050 to 81.6 and 79.4 years respectively, a reason that has allowed new projects to arise in this population in different contexts for a fuller life (Ceh , 2020; INAPAM, 2014).
The contexts most approached by the elderly person are educational and work without leaving aside the health context, that is, the elderly adult, in addition to acquiring a stable and functional organic level, allows them to propose new tasks such as continuing to train through courses, diplomas and even higher level studies; as well as establishing new goals or projects of a work nature that is not only the search for material or economic well-being, but also personal objectives that allow a realization as a human being.

It has been proposed by the World Health Organization (WHO, 2014) in the Second Assembly on Aging, that the elderly have rights such as: to their independence, to food, housing, education, and also to protection that safeguards it from the exclusion mentioned in article 12, on page 4 the following:

"Older persons must have the opportunity to work until they want to and are able to do so while performing satisfactory, productive jobs and continue to have access to education and training programs" (Mogollón, 2012, p 57).

As already well said, these academic and work needs arise, which at the same time have a favorable impact on other areas such as cognitive, affective and social, which will allow more favorable contexts for inclusion in the different scenarios of their activities everyday. Hence the importance of inquiring about this phenomenon of educational and labor inclusion in the elderly population at the Higher level.

\section{Background}

There are various research works that report statistical figures of university activities of the elderly population both in the student and work settings. One of these works is that reported by Saldaña-Ibarra and Hernández-Guerson (2017), with the emergence of the project of the formation of the Universities of the Third Age (UTE) in 1973, in Toulouse, France due to a need manifested by the population itself in this age group. This initiative was followed by some European countries and the United States of America, where the formation of new UTEs was also promoted. 
The experience of these countries generated that, according to the purposes and organizational characteristics of the different educational institutions, three models were proposed: 1) The French Model, 2) The British or Cambridge Model and 3) The Hybrid Model or Mixed. Hence, this trend was also manifested in countries such as Mexico, among others that make up Latin America (Ramírez \& VíctorRamírez, 2010; Saldaña-Ibarra \& HernándezGuerson, 2017).

This phenomenon, which also impacted in Mexico, allowed its participation in the UTE NETWORK, with the first University of the Third Age being founded in Mexico City in 2009 (Saldaña-Ibarra \& Hernández-Guerson, 2017; Velis, Viteri, Terranova \& Ordoñez, 2018).

The National Autonomous University of Mexico (UNAM), was included in this project in 2011, when creating the Interdisciplinary University Seminar on Aging and Old Age (SUIEV), whose purpose was to build networks, collaborative activities and interdisciplinary projects, which promote UNAM. In 2013, thanks to SUIEV, the University Network on Aging and Old Age was formed, made up of 21 academic entities, with the purpose of analyzing and studying the elderly population from different perspectives on research, training, updating and training. (Narro-Robles, Martuscelli-Quintana \& Barzana-García, 2012; Saldaña-Ibarra \& Hernández-Guerson, 2017).

Other states joined this proposal to name a few, such as Nuevo León with the Binational University of the Third Age (U3E), which has the purpose of integrating Older Adults into society, contributing to the right to a life with quality; in addition to receiving education and training for work (Saldaña-Ibarra \& HernándezGuerson, 2017; Vázquez-Galicia, 2009);

The state of Puebla, through the IberoAmerican University, proposed a university program to strengthen the knowledge and experience of older adults through a diploma course in which different topics were addressed; Another state was Yucatán, with the participation of the Marista University, which created a space for older adults to develop their human potentialities, and the possibility of acquiring tools for a full life and enriching their cultural knowledge, through a diploma addressing the topics such as: healthy eating; Indoor growth,
Cinema and society, Human development, Brain gymnastics, among others, and the state of Oaxaca participated with the University of the Elderly (UNIDAM), through the Diploma of the Elderly Host of Oaxaca, where older adults are trained as hosts, to meet the needs not only of its elderly population, but also of other elderly people who visit Oaxaca (Saldaña-Ibarra \& Hernández-Guerson, 2017; Vázquez-Galicia, 2009).

As mentioned, in Mexico, various university institutions have continued to promote the participation of the elderly until today, another clear example was the proposal to build the Veracruzana University for the Elderly under the axis of an intergenerational program, where the community participates of academics who are older adults (Saldaña-Ibarra \& Hernández-Guerson, 2017). Another institution that has not been the exception is the Autonomous University of the State of Morelos (UAEM). In 2013, by agreement of the University Council, the University Program for Educational Inclusion and Attention to Diversity was implemented (now known as the Unit for Inclusive Education and Attention to Diversity).

In a recent study, the needs and supports provided in the cognitive, neurobiological and socio-affective aspects were identified and analyzed during the process of educational inclusion of the older adult population at the higher level of the UAEM, where it was carried out by the Unit for Education Inclusion and Attention to Diversity in a census for the period between 2015-2017, identifying a population of 320 older adults classified in the following categories: 2 students, 269 academics and 49 administrative workers, which suggests that these figures will increase (Moreno-Aguirre et al., 2019; UAEM, 2012-2018a). With these findings, the need arises to analyze this process of educational and labor inclusion of the elderly in higher education of the UAEM, to identify the supports that are currently provided and what needs still exist, as well as the scope and limitations of this process, already that the results will make it possible to establish improvement strategies in educational and labor inclusion

\section{Objective}

Analyze the process of educational and labor inclusion of the elderly in higher education of the UAEM.

MORENO-AGUIRRE, Alma Janeth, GUAJARDO-RAMOS, Eliseo, ORTIZ-RODRÍGUEZ, María Araceli and DELGADO-SÁNCHEZ, Ulises. Educational and labor inclusion of the elderly in the UAEM. ECORFAN Journal-Republic of Colombia. 2020 


\section{Method}

An analysis of the process of educational and labor inclusion in the older adult population who are workers and students of the UAEM was carried out.

The analyzed population was obtained from a database that was formed by the application of questionnaires to administrative and academic personnel of the UAEM in 2018, to identify a condition or situation of vulnerability, through a census carried out by the Unit for Attention to the Diversity and Inclusive Education. The inclusion criteria to make up the sample were under these premises: 1) that the worker or student is included in the referred database, 2) that they have an age equal to or greater than 60 years and 3) that they are active personnel ( not retired or pensioned staff). Main characteristics were identified in relation to the variables considered in the database and a descriptive analysis was carried out.

The needs of the studied population, the conditions in which they are found and the support provided were identified. This analysis was carried out from the cognitive, neurobiological perspective with or without the presence of disability or chronic-degenerative disease; as well as the search for socio-affective indicators or other psychosocial factors that may impact on this inclusion process. For the statistical analysis, the SPSS version 22.0 program and Office 365 Excel were used.

\section{Results}

The database was analyzed, identifying 347 people with administrative and academic activities (teachers and students) of the UAEM in a condition or situation of vulnerability, from which the data of 311 people were selected according to the inclusion criteria to conform the sample, where $27.7 \%(\mathrm{~N}=86)$ were women and $72.3 \%(\mathrm{~N}=225)$ men. The mean age of the study sample was 65 years $(\mathrm{SD} \pm 5)$, with a minimum age range of 60 years and a maximum of 83 years. $26.7 \%(\mathrm{~N}=83)$ of the sample were administrative personnel and $73.7 \%(\mathrm{~N}=228)$ were academic (Teachers / Students). Both administrative and academic workers had an average work seniority (years worked) of 18 years (SD \pm 10.6 years), with a minimum time range of less than one year in service for $1.6 \%$ $(\mathrm{N}=5)$ of the sample and a maximum time of 49 years worked.
Another parameter analyzed was the presence of disability and only $0.6 \%(\mathrm{~N}=2)$ of the sample with motor disability and $100 \%$ of the sample with a condition or situation of vulnerability were reported because they were within the age range of 60 or furthermore, no other disabilities were reported in this database.

The supports provided by the institution to promote educational and labor inclusion were the following: architectural modifications for admission and permanence in university facilities in buildings for administrative activity, in academic units and research centers. About support for the academic population (teachers / students), adjustments have been made to access information in libraries and documentary information centers in each academic unit and research centers.

In addition, since 2013, strategies have been implemented to eliminate the administrative barriers of admission and permanence to the university to population with disabilities and / or with some other condition or situation of vulnerability, one of them is the application of a differentiated general examination that has allowed the entry of a large number of applicants to study a bachelor's degree, another strategy is to carry out curricular adjustments (now reasonable adjustments) to the study programs, as well as the formation of Support Services Units for Educational Inclusion (USAIE -UAEM) and the University Units of Community Care (UUAC). As mentioned in the background section, at the beginning all the support was aimed at the student population with disabilities, but now the student population made up of older adults is also contemplated and its vision has recently been expanded to the population of university workers (administrative and academic), which fall within this age group.

The database could not accurately identify some important aspects that should be considered in the elderly population, of neurobiological aspects such as chronicdegenerative diseases, or other conditions such as oncological, cognitive, neurological, mental, among others. Nor was the information accurate to identify emotional, social, and cultural factors that could be barriers to educational and labor inclusion. These limitations within the database were considered for the development of strategies. 


\section{Important research considerations}

Based on the results found of the older adult population of administrative and academic (teachers / students) in the UAEM, a favorable point is that it is already considered as a population that requires specific support like any other group in a vulnerable situation; However, more dimensions still need to be evaluated to more precisely identify the possible barriers that impede the process of educational and labor inclusion. It is observed that there is a predominance of the male population than female $(27.7 \%$ women and $72.3 \%$ men), so this proportion must be considered due to the possible health problems that may occur more frequently based on the sex of person.

According to the reports of the total population aged 60 years or over in 2014, there is a predominance of chronic-degenerative pathologies such as systemic arterial hypertension in $40 \%$, diabetes mellitus in $24.3 \%$ and hypercholesterolemia in $20.4 \%$ in the global population, but differences by sex are observed, that is, there is a higher percentage in these three pathologies that occur more frequently in women than in men. Such is the case of arterial hypertension in women it is $46.2 \%$ and in men it is $32.9 \%$, diabetes mellitus is $25.8 \%$ in women and in men it is $22.4 \%$, in the case of hypercholesterolemia in women it was $23.6 \%$ and $16.7 \%$ in men.

Others Important diseases reported are heart disease, stroke, and cancer. In mental pathology there may be significant depression in $17.6 \%$, a more frequent cognitive deterioration in women in $22.1 \%$ and in men $12.5 \%, 22.1 \%$ of women and $12.5 \%$ of men; $7.3 \%$ present cognitive impairment, $8.3 \%$ of women and $6.3 \%$ of men; and $7.9 \%$ suffer from dementia, $9.1 \%$ are women and $6.9 \%$ are men. (INEGI, 2012; INAPAM, 2014).

Regarding the activity within the UAEM, $26.7 \%(\mathrm{~N}=83)$ of the sample were administrative personnel and $73.7 \%$ were academic (teachers / students), these results indicate the importance of developing strategies in the different areas (administrative and academic), although the teacher / student population predominates, both contexts are important for both the work and academic environment to be inclusive, as was done by the Veracruz University.
Where it involved its teachers who were older adults to participate in the project to promote an intergenerational university space between teachers and students where the active aging of its university community where there are older adults was promoted, with this it was possible to identify the phases and negotiations, ends, facilitators and obstacles to generate a university policy and at the same a change paradigm of aging, the possibility of growth and academic personal development of the adult To major, the development it can have in a university community and the promotion of health.

All this proposal favors labor and educational inclusion (Benet-Gil, 2020; Saldaña-Ibarra \& Hernández-Guerson, 2017). Another reference is the awareness programs for the perception and attitude of the teacher towards educational inclusion in students with disabilities at the higher level, where the perception and attitude of teachers towards the educational inclusion of deaf students in the UAEM has been investigated, facilitating the design of awareness programs, since the role of the university teacher is fundamental and a key point for the educational inclusion process to take place (Álvarez, 2020; Valle-Aparicio, 2014).

Another point to consider is whether there is the presence or absence of disability. In the case of the sample made up, only motor disability was recorded ( $0.6 \%$ of the sample), so other possible disabilities will have to be investigated through other instruments. Regarding motor disability in the elderly, there are various instruments to assess it and determine functional capacity, such as the scales 1) "Basic Activities of Daily Living" (ABVD) and 2) "Instrumental Activities of Daily Living" ( AIVD), among others. (INSP, ENSANUT, 2012). Motor disability can be considered an important barrier to the process of labor or educational inclusion and impact other areas of development that affect the quality of life. It is important to make modifications to the instrument that formed the database, in order to focus it more precisely on the dimensions mentioned in order to obtain more specific data and thus continue to develop strategies that can gradually solve the current problem and future situations that could be foreseen when knowing possibilities situations that may be barriers of different kinds that affect the inclusion process. 


\section{Acknowledgments}

We thank the Academic Group for Transdisciplinary Studies on Vulnerable Groups (UAEMOR-CA-142), the Faculty of Human Communication, the Faculty of Nutrition and the Unit for Educational Inclusion and Attention to Diversity of the UAEM for the support provided.

\section{Conclusions}

The various programs focused on the well-being of the elderly have allowed an increase in life expectancy and therefore an increase in needs. If the average life span in this population is higher, there will be a percentage of it that will continue to be independent and functional not only in the economic aspect, but also in its cognitive, neurobiological and socio-affective state in general, allowing a better quality of life and inclusion in the different scenarios of their daily activities such as academic and work.

Therefore, age should not be an excluding element, in any condition of vulnerability, it is necessary to favor the elimination of biological, psychological, affective, educational, labor, social, cultural barriers, among others, to achieve the inclusion process.

In addition, it is important to continue advancing with public policies at the national and international level in favor of the rights and needs of the elderly, which is why this motivates us to continue building an inclusive culture in all contexts.

\section{References}

Álvarez, M. K. G. (2020). La percepción y actitud del docente de la atención educativa para la inclusión de estudiantes sordos de la UAEM. http://riaa.uaem.mx:8080/xmlui/bitstream/handl e/20.500.12055/1233/GAAMLR09T.pdf?seque nce $=1 \&$ isAllowed $=y$

Benavides-Caro, C.A. (2017). Deterioro cognitivo en el adulto mayor. Revista Mexicana de Anestesiología.40 (29), 107-112.

Benet-Gil, A. (2020). Desarrollo de políticas inclusivas en la educación superior. Convergencia, 27. http://www.scielo.org.mx/pdf/conver/v27/24485799-conver-27-e11120.pdf
Ceh, J. G. G. (2020). La tercera edad: el derecho al aprendizaje a lo largo de la vida. RIDE Revista Iberoamericana para la Investigación y el Desarrollo Educativo, 10(20). DOI:https://doi.org/10.23913/ride.v10i20.670 https://www.ride.org.mx/index.php/RIDE/articl e/view/670/2462

INAPAM. 2014. Presentación en el Segundo Foro Internacional sobre los derechos humanos de los adultos mayores, Ciudad de México, disponible en www.cepal.org

INEGI. (2012). Estudio Nacional de Salud y Envejecimiento en México (ENASEM), Base de datos, (Instituto Nacional de Estadística y Geografía/ Instituto Nacional de Geriatría/ Instituto Nacional de Salud Pública/ University of Pennsylvania/ University of Wisconsin Madison).

Instituto Nacional de Salud Pública (INSP). (2012). Encuesta Nacional de Salud y Nutrición (ENSANUT). Base de datos.

Mogollón, E. (2012). Una perspectiva integral del adulto mayor en el contexto de la educación. Revista Interamericana de Educación de Adultos, 34 (1), 56-74. ISSN: 0188-8838. http://www.redalyc.org/articulo.oa?id=4575450 90005

Moreno-Aguirre, A.J., Ortiz-Rodríguez, M.A., Cruz-Abarca, L. \& Capistrán-Pérez, L.P. (2019). Inclusión Educativa del adulto mayor en la UAEM. Revista de Teoría Educativa, 3(9), 1-9. https://www.ecorfan.org/republicofperu/researc $\mathrm{h} \_$journals/Revista_de_Teoria_Educativa/vol3n um9/Revista_de_Teor\%C3\%ADa_Educativa_ V3_N9_1.pdf

Narro-Robles, J., Martuscelli- Quintana, J. \& Barzana-García, E. (Coord.). (2012) Plan de diez años para desarrollar el Sistema Educativo Nacional. [En línea]. México: Dirección General de Publicaciones y Fomento Editorial, UNAM http://www.planeducativonacional.unam.mx

OMS. (2014) "Envejecer bien, una prioridad mundial", Consultado en http://www.who.int/ageing/es/ 
Ramírez, L. V. \& Víctor-Ramírez, A. C. (2010). Educación para adultos en el siglo XXI: análisis del modelo de educación para la vida y el trabajo en México ¿avances o retrocesos? Tiempo de Educar, 11(21), 59-78. ISSN: 1665-0824. http://www.redalyc.org/articulo.oa?id=3111616 3004

Saldaña-Ibarra S.A. \& Hernández-Guerson E. (2017). Universidad del Adulto Mayor: Un nuevo escenario de desafíos y de oportunidades. Memoria de congreso electrónica: XIV Congreso Internacional de Investigación Educativa COMIE, San Luis Potosí 2017. Universidad Veracruzana. http://www.comie.org.mx/congreso/memoriaele ctronica/v14/doc/2599.pdf

UAEM. (2012-2018a). Manual Azul. http://www.uaem.mx/sites/default/files/inclusio n-y-atencion-diversidad/manual-azul.pdf

UAEM. (2012-2018b). Orientaciones Teóricas y Metodológicas esenciales para diseñar Adecuaciones Curriculares en Educación Superior. Programa Universitario en Educación Inclusiva y Atención a la Diversidad. Universidad Autónoma del Estado de Morelos: México.

http://www.uaem.mx/sites/default/files/orientac iones-teoricas.pdf

Valle-Aparicio, J.E. (2014). Educación permanente: los programas universitarios para mayores en España como respuesta a una nueva realidad social. Revista de la Educación Superior. XLIII (3); No.171, 117-138. ISSN: 0185-2760.

https://doi.org/10.1016/j.resu.2015.03.003

Vázquez-Galicia, L. (2009). ¿Estudias y trabajas? Los estudiantes trabajadores de la Universidad Autónoma Metropolitana, Unidad Azcapotzalco. Revista Latinoamericana de Estudios Educativos (México).XXXIX (3-4), 121-149.

http://www.redalyc.org/pdf/270/27015078006.p df

Velis, L., Viteri, E., Terranova, E., \& Ordoñez, S. (2018). Nuevas tecnologías de la comunicación y capacidad cognitiva de adultos mayores. Universidad, Ciencia y Tecnología. 22 (89), 82-87. ISSN: 2542-3401. http://uctunexpo.autanabooks.com/index.php/uc t/article/view/35/38 